\title{
KETAHANAN VARIETAS KEDELAI TERHADAP HAMA BELALANG PADA PERLAKUAN INSEKTISIDA HAYATI (Beauveria bassiana)
}

\author{
The Resistance of Soybean Varieties Against The Locust On \\ Biological Pesticide Treatment Beauveria bassiana
Gayuh Prasetyo Budi *), Teguh Pribadi, Dyatri Nururrahmah
Prodi Agroteknologi FP Universitas Muhammadiyah Purwokerto \\ *) e-mail : pbgayuh@gmail.com
}

\begin{abstract}
ABSTRAK
Tujuan penelitian untuk mengetahui intensitas serangan belalang, pertumbuhan dan hasil beberapa varietas kedelai pada perlakuan agens hayati Beauveria bassiana. Penelitian dilakukan pada media tanah dalam polybag bertempat di Green House FP UMP di Desa Karangsari, Kecamatan Kembaran, Kabupaten Banyumas dengan ketinggian tempat $90 \mathrm{~m}$ dpl. Menggunakan Rancangan Acak Lengkap 2 faktor dengan 4 ulangan. Faktor 1. Varietas kedelai terdiri atas : $\mathrm{V}_{1}$ : Argomulyo, $\mathrm{V}_{2}:$ Baluran, $\mathrm{V}_{3}$ : Ijen, $\mathrm{V}_{4}:$ Kaba. Faktor 2 . Agens Hayati $B$. bassiana terdiri atas : K0 : tanpa diberi B. bassiana, K1 : diberi $B$. bassiana $6 \mathrm{~g} / \mathrm{l}$ aquades. Hasil penelitian menunjukkan Perlakuan $B$. bassiana berpengaruh nyata terhadap intensitas serangan belalang. Tanaman kedelai yang diaplikasi $B$. bassiana (K1) menunjukkan intensitas serangan belalang : 8,66\% sedangkan yang tidak diaplikasikan $B$. bassiana $(\mathrm{K} 0)$ menunjukkan intensitas serangan belalang : $17,53 \%$. Perlakuan varietas kedelai berpengaruh nyata terhadap tinggi tanaman $70 \mathrm{hst}$, jumlah polong total/tanaman, jumlah polong isi/tanaman, jumlah biji/tanaman dan berat biji/tanaman. Varietas Kaba (V2) menunjukkan berat biji/tanaman yang paling berat : $5,89 \mathrm{~g} /$ tanaman. Interaksi antara perlakuan varietas kedelai dan B. bassiana tidak berpangaruh nyata terhadap semua variabel yang diamati.
\end{abstract}

Kata kunci : Intensitas Kerusakan Belalang, Kedelai, Beauveria bassiana

\begin{abstract}
The objective of this research was to determine the intensity of locust attack, growth and yield of several soybean varieties in the treatment of biological agents Beauveria bassiana. The research was conducted on soil media in polybags located at the Green House, Faculty of Agriculture Muhammadiyah Purwokerto University, at Karangsari Village, Kembaran, Banyumas, the altitude $90 \mathrm{~m}$ above sea level. The experiment used a Completely Randomized Design with 2 factors and 4 replications. Factor 1 . Soybean Variety, consisted of $\mathrm{V}_{1}$ : Argomulyo, $\mathrm{V}_{2}$ : Baluran, $\mathrm{V}_{3}:$ Ijen, $\mathrm{V}_{4}:$ Kaba, Factor 2. Biological agents, consisted of without B. bassiana $(K O)$,

given $B$. bassiana $6 g / l$ aquades. The results showed that B. bassiana treatment significantly affected the intensity of locust attack. Soybean plants that applied B. bassiana (K1) showed the intensity of locust attack: $8.66 \%$ while those that were not applied B. bassiana (KO) showed the intensity of locust attack: $17.53 \%$. The treatment of soybean varieties significantly affected the plant height of 70 days after planting, total number of pods / plants, number of filled pods/plants, number of seeds/plants and weight of seeds/plants. Kaba variety (V4) shows the weight of seeds/plants the heaviest : $5.89 \mathrm{~g} /$ plant. The interaction between the treatments of soybean varieties and B. bassiana had no significant effect on all observed variables.
\end{abstract}

Key Words : The Intensity of Locust Attack, Soybeans, Beauveria bassiana 


\section{PENDAHULUAN}

Kedelai merupakan komoditi yang banyak dimanfaatkan untuk membuat bahan makanan berupa : tempe, tahu, tauco, kecap dan susu kedelai yang mempunyai nilai gizi tinggi sehingga dapat bermanfaat untuk meningkatkan kesehatan dan gizi masyarakat. Komoditi ini mempunyai kandungan protein : 35\%-38\% dan semua asam amino esensial. Dalam 100g kedelai kuning kering terkandung : 400,0 kal kalori, 35,1 g protein, 17,7 g lemak, vitamin dan mineral lainnya. Setiap $1 \mathrm{~g}$ asam amino kedelai kuning mengandung $494 \mathrm{mg}$ leusin, $391 \mathrm{mg}$ lysine, $84 \mathrm{mg}$ methionine, $81 \mathrm{mg}$ cystine, $341 \mathrm{mg}$ phenylalanine, $165 \mathrm{mg}$ tirosin, $247 \mathrm{mg}$ threonine, $76 \mathrm{mg}$ tryptophane, dan 291 mg valine (Hermana, 2003).

Setiap tahunnya Indonesia hanya mampu memenuhi kebutuhan kedelai nasional kurang dari 50\% dari kebutuhan sekitar 2,25 juta ton per tahun (Pusat Data dan Sistem Informasi Pertanian, 2015). Hal ini menjadikan ketergantungan akan kedelai impor tidak bisa dihindari. Rendahnya produksi kedelai nasional salah satunya disebabkan oleh serangan belalang.

Hama belalang cukup merugikan karena memakan daun dan tangkai muda tanaman kedelai sehingga produksi kedelai menurun bisa mencapai 70\% (Mamonto Ris,2016). Usaha pengendalian hama belalang yang sering dilakukan petani adalah dengan menggunakan insektisida kimia. Penggunaan insektisida banyak menimbulkan dampak negatif berupa resistensi hama, pencemaran udara dan tanah, resurjensi dan munculnya hama sekunder (Untung, 1993). Oleh karena itu perlu dicari cara pengendalian belalang yang lebih aman terhadap lingkungan salah satunya yaitu dengan pemanfaatan agens hayati, jamur Beauveria bassiana Vuill (Kartosuwondo, 2000).

\section{METODE PENELITIAN}

Penelitian dilakukan pada media tanah yang ditempatkan dalam polybag, dilaksanakan mulai Maret 2019 sampai dengan Juni 2019, menggunakan Rancangan Acak Lengkap (RAL). dua faktor perlakuan. Faktor 1. Varietas kedelai terdiri atas : $\mathrm{V}_{1}$ : Argomulyo, $\mathrm{V}_{2}$ : Baluran, $\mathrm{V}_{3}:$ Ijen, $\mathrm{V}_{4}$ : Kaba. Faktor 2. Agens Hayati B bassiana 
terdiri atas : K0 : tanpa diberi B. bassiana, K1 : diberi B. bassiana 6g/l aquades. Masingmasing kombinasi perlakuan diulang 4 kali

\section{HASIL DAN PEMBAHASAN}

Hasil analisis statistik data pada Tabel 1, Tabel 2 dan Tabel 3 menunjukkan bahwa perlakuan varietas kedelai berpengaruh nyata terhadap tinggi tanaman, jumlah polong total/tanaman, jumlah polong isi/tanaman, jumlah biji/tanaman, berat biji/tanaman. Perlakuan $B$. bassiana berpengaruh nyata terhadap intensitas serangan hama belalang dan tidak berpengaruh nyata terhadap variabel lainnya. Tidak terdapat interaksi nyata diantara 2 faktor perlakuan yang dicoba.

Tabel 1. Efektivitas Jamur B. bassiana terhadap Pertumbuhan Vegetatif Empat Varietas Tanaman Kedelai (Glycine max (L.) Merill)

Tanpa B. bassiana (K0)

Diberi B. bassiana (K1)

V1K0

V1K1

V2K0

$\mathrm{V} 2 \mathrm{~K} 1$

V3K0

V3K1

V4K0

V4K1

71,75
72,10
71,50
72,00
64,47
67,47
77,25
77,50
73,80
71,42

71,75

72,10

71,50

72,00

64,47

67,47

77,25

77,50

71,42

$\begin{array}{cc}37,64 \mathrm{a} & 0,36 \\ 37,25 \mathrm{a} & 0,36 \\ 35,32 \mathrm{a} & 0,30 \\ 39,61 \mathrm{a} & 0,38 \\ 36,99 \mathrm{a} & 0,35 \\ 35,96 \mathrm{a} & 0,38 \\ 39,30 & 0,40 \\ 33,04 & 0,35 \\ 38,95 & 0,38 \\ 40,39 & 0,35\end{array}$

0,36

0,36

0,30

0,38

0,35

0,38

0,40

0,35

0,35

Keterangan : Angka yang diikuti dengan huruf yang sama pada kolom yang sama menunjukkan tidak berbeda nyata dari setiap perlakuan yang diberikan menurut uji DMRT 5\%

\section{Tinggi Tanaman 70 hst}

Berdasarkan hasil analisis statistik perlakuan varietas mempunyai pengaruh yang nyata terhadap tinggi tanaman pada umur 70 hst. Dilihat dari hasil analisis statistik 
(Tabel 1) varietas Argomulyo (V1) mempunyai tinggi : 71,75 cm, varietas Baluran (V2) : 65,97 cm, varietas Ijen (V3) : 77,37cm dan varietas Kaba (V4) : 72,61 cm.

Pertumbuhan tinggi tanaman yang lebih tinggi ialah pada varietas Ijen (V3). Pada umur 70 hst tinggi tanaman yang paling rendah ialah varietas Baluran : 65,97 cm. Hal ini dapat terjadi karena pada masing-masing varietas memiliki karakteristik pertumbuhan yang berbeda-beda. Peningkatan ukuran tinggi tanaman pada ke empat varietas tanaman kedelai secara drastis secara umum terjadi pada umur 14 sampai 42 hst, sedangkan pada umur 42 hingga 70 hst kenaikannya landai. Perlakuan B. bassiana yang diberikan tidak berpengaruh nyata terhadap tinggi tanaman. Interaksi antara perlakuan varietas dengan B. bassiana juga tidak berpengaruh nyata terhadap pertumbuhan tinggi tanaman pada umur 70 hst.

\section{Diameter Tajuk 70 hst}

Berdasarkan hasil analisis statistik perlakuan varietas kedelai, B. bassiana dan interaksi kedua faktor perlakuan tidak berpengaruh nyata terhadap diameter tajuk pada umur 70 hst. Dilihat dari Tabel 1 ke empat varietas mempunyai pertumbuhan diameter tajuk yang relatif sama, pada varietas Argomulyo mempunyai diameter tajuk : $37,47 \mathrm{~cm}$, Baluran : 36,47 cm, Ijen : 36,17 dan Kaba : 39,67 cm.

\section{Diameter Batang 70 hst}

Berdasarkan hasil analisis statistik perlakuan varietas tidak berpengaruh nyata terhadap diameter batang pada umur 70 hst. Berdasarkan analisis statistik (Tabel 1), ke empat varietas mempunyai pertumbuhan diameter batang yang relatif sama, pada varietas Argomulyo mempunyai sebesar 0,34 cm, Baluran : 0,36 cm, Ijen : 0,37 cm dan Kaba : 0,36 cm.

Perlakuan agens hayati yang diberikan terhadap tanaman kedelai tidak berpengaruh nyata terhadap diameter batang. Interaksi antara perlakuan varietas dengan Beauveria bassiana juga tidak berpengaruh nyata terhadap diameter batang pada umur 70 hst. 
Tabel 2. Efektivitas Agens Hayati Beauveria bassiana terhadap Hasil Empat Varietas Tanaman Kedelai (Glycine max (L.) Merill)

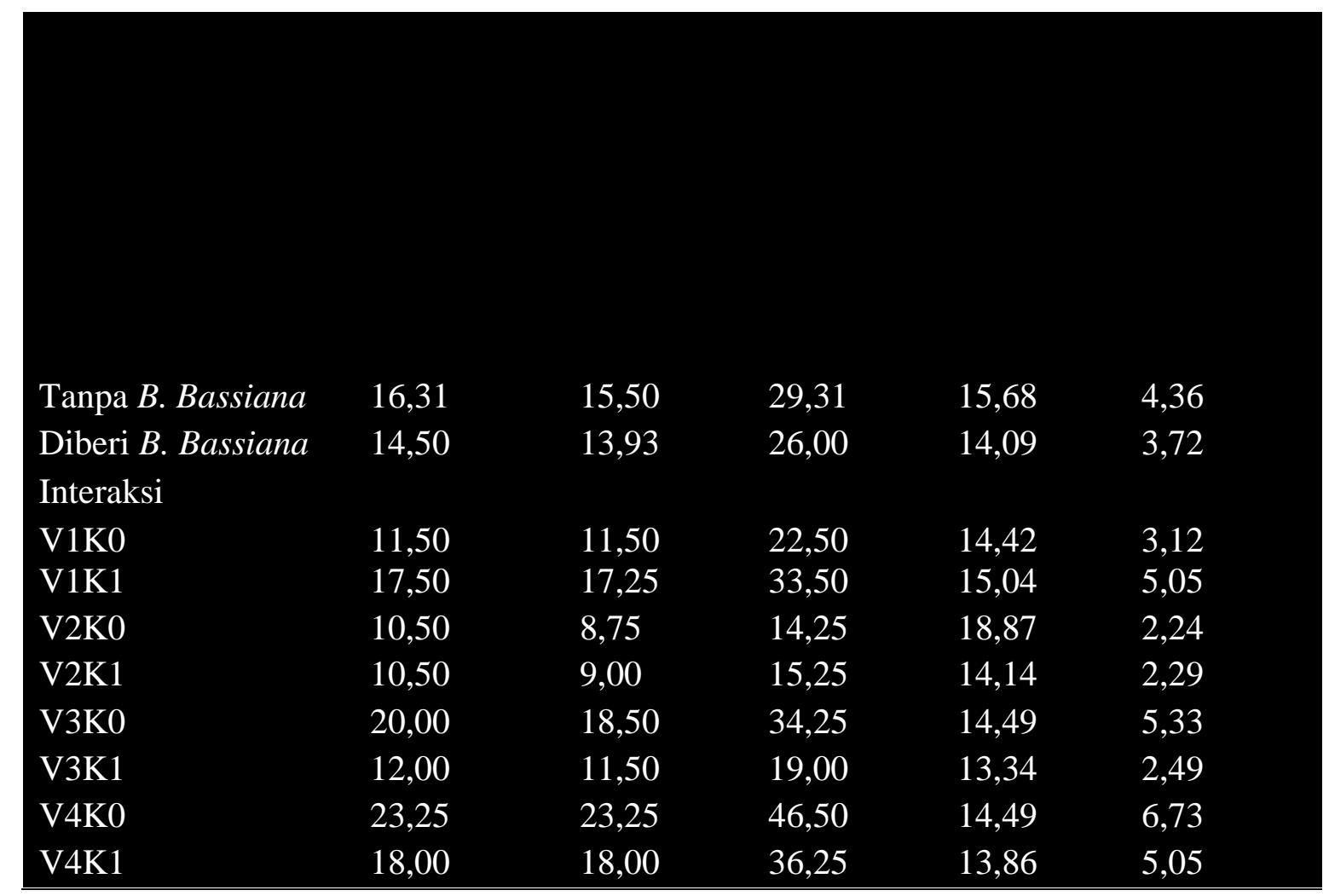

Keterangan: Angka yang diikuti dengan huruf yang sama pada kolom yang sama menunjukkan tidak berbeda nyata dari setiap perlakuan yang diberikan menurut uji DMRT 5\%

\section{Jumlah Polong Total/Tanaman}

Tabel 2 menunjukkan bahwa perlakuan varietas berpengaruh nyata terhadap jumlah polong total per tanaman. Varietas Kaba mempunyai jumlah polong total per tanaman : 20,62 polong secara nyata lebih banyak dari Argomulyo (V1) dan baluran (V2), sedangkan hasil jumlah polong total per tanaman yang paling sedikit pada varietas Baluran : 10,15 polong.

Perlakuan agens hayati $B$. bassiana tidak berpengaruh nyata terhadap jumlah polong total per tanaman yang dihasilkan oleh tanaman kedelai. Berdasarkan hasil analisis statistik terhadap jumlah polong total per tanaman (Tabel 2), pada perlakuan 
yang tidak diaplikasikan B. bassiana (K0) menghasilkan jumlah polong total per tanaman 16,31 polong sedangkan yang diaplikasikan B. bassiana (K1) menghasilkan jumlah polong total per tanaman sebesar 14,5 polong dimana hasil keduanya tidak berbeda nyata. Interaksi antara perlakuan varietas dengan $B$. bassiana tidak berpengaruh nyata terhadap jumlah polong total per tanaman.

\section{Jumlah Polong Isi/Tanaman}

Hasil analisis statistik (Tabel 2) menunjukkan bahwa, perlakuan varietas mempunyai pengaruh yang nyata terhadap jumlah polong isi per tanaman. Varietas Kaba mempunyai jumlah polong isi per tanaman : 20,62 polong secara nyata lebih banyak dari Argomulyo (V1) dan baluran (V2), sedangkan hasil jumlah polong isi per tanaman yang paling sedikit pada varietas Baluran : 8,87 polong.

Perlakuan agens hayati B. bassiana tidak berpengaruh nyata terhadap jumlah polong isi yang dihasilkan oleh tanaman kedelai. Berdasarkan hasil analisis statistik terhadap jumlah polong isi per tanaman (Tabel 2), pada perlakuan yang tidak diaplikasikan B. bassiana (K0) menghasilkan jumlah polong isi : 15,5 polong sedangkan yang diaplikasikan B. bassiana (K1) menghasilkan jumlah polong isi : 13,94 polong dimana hasil keduanya tidak berbeda nyata.. Interaksi antara perlakuan varietas dengan $B$. bassiana tidak berpengaruh nyata terhadap jumlah polong isi per tanaman.

\section{Jumlah Biji/Tanaman}

Hasil analisis statistik (Tabel 2) menunjukkan bahwa, perlakuan varietas mempunyai pengaruh yang nyata terhadap jumlah biji per tanaman. Varietas Kaba (V4) mempunyai jumlah biji per tanaman : 41,37 biji secara nyata lebih banyak dari Argomulyo (V1) dan Ijen (V3),, sedangkan jumlah biji yang paling sedikit pada varietas Baluran (V2) : 14,75 biji.

Perlakuan agens hayati $B$. bassiana tidak berpengaruh nyata terhadap jumlah biji per tanaman yang dihasilkan oleh tanaman kedelai. Berdasarkan hasil analisis statistik rata-rata jumlah jumlah biji (Tabel 2), pada perlakuan yang tidak diaplikasikan $B$. bassiana (K0) menghasilkan jumlah biji per tanaman 29,31 biji sedangakan yang diaplikasikan B. bassiana (K1) menghasilkan jumlah biji : 14,5 biji dimana hasil 
keduanya tidak berbeda nyata. Interaksi antara perlakuan varietas kedelai dengan $B$. bassiana tidak berpengaruh nyata terhadap jumlah biji per tanaman.

\section{Berat 100 biji}

Hasil analisis statistik (Tabel 2) menunjukkan bahwa, perlakuan varietas tidak berpengaruh nyata terhadap berat 100 biji. Perlakuan agens hayati $B$. bassiana menunjukkan pengaruh yang tidak nyata terhadap berat 100 biji. Interaksi antara perlakuan varietas dan $B$. bassiana menunjukkan pengaruh yang tidak nyata terhadap berat 100 biji.

Tabel 3. Perlakuan Varietas Kedelai dan B. bassiana terhadap Intensitas Serangan Belalang

B. Basiana

Tanpa B. bassiana $(K 0)$

Diberi $B$. bassiana $(K 1)$

Interaksi

V1K0

V1K1

V2K0

V2K1

V3K0

V3K1

V4K0

V4K1
$17,53 \mathrm{~b}$

8,66 a

16,37

7,75

14,37

7,50

23,75

15,00

15,62

4,37

Keterangan : Angka yang diikuti dengan huruf yang sama pada kolom yang sama menunjukkan tidak berbeda nyata dari setiap perlakuan yang diberikan menurut uji DMRT 5\%

\section{Berat Biji/Tanaman}

Hasil analisis statistik (Tabel 2) menunjukkan bahwa, perlakuan varietas mempunyai pengaruh yang nyata terhadap berat biji per tanaman. Varietas Kaba (V4) mempunyai berat biji per tanaman : 5,89 g, sedangkan varietas Baluran (V2) : 2,26 g. 
Perlakuan agens hayati $B$. bassiana tidak berpengaruh nyata terhadap berat biji per tanaman Berdasarkan hasil analisis statistik (Tabel 2) dimana hasil kedua nya relatif sama. Interaksi antara perlauan varietas dan B. bassiana menunjukkan perlakuan yang tidak nyata terhadap berat biji per tanaman.

\section{Intensitas Serangan Belalang}

Hasil analisis statistik (Tabel 3) menunjukkan bahwa, perlakuan varietas mempunyai pengaruh yang tidak nyata terhadap intensitas serangan hama belalang. Berdasarkan diagram intensitas serangan belalang pada empat varietas kedelai (Gambar 1) serangan hama paling tinggi pada varietas Ijen (V3) : 19,37\% dan paling rendah varietas Kaba (V4) : $10 \%$.

Perlakuan konsentrasi $B$. bassiana berpengaruh nyata terhadap intensitas serangan hama. Berdasarkan hasil analisis statistik (Tabel 3), intensitas serangan pada perlakuan (K0) yang tidak diaplikasikan B. bassiana paling yaitu : 17,53\% sedangkan yang diaplikasi B. bassiana intensitas serangan hama sebesar : 8,66\%. Interaksi antara perlakuan varietas dengan $B$. bassiana tidak berpengaruh nyata terhadap intensitas serangan hama.

\section{Pengaruh B. bassiana terhadap Intensitas Serangan Belalang, Pertumbuhan dan Hasil Tanaman Kedelai (Glycine max L.).}

Berdasarkan hasil analisis statistik, perlakuan $B$. bassiana berpengaruh nyata terhadap intensitas serangan hama dan tidak berpengaruh nyata terhadap variabel tinggi tanaman, diameter tajuk, diameter batang, jumlah polong total per tanaman, jumlah polong isi per tanaman, jumlah biji per tanaman, berat 100 biji dan berat biji per tanaman. Berdasarkan hasil analisis statistik (Tabel 3), intensitas serangan pada tanaman kedelai yang tidak diaplikasikan B. bassiana (K0) menunjukkan intensitas serangan hama sebesar : $17,53 \%$ sedangkan yang diberikan aplikasi B. bassiana (K1) intensitas serangan hama hanya : $8,66 \%$.

Menurut Kumendong (1995), gejala awal infeksi patogen B. bassiana pada serangga yang terinfeksi adalah serangga kelihatan lemah, tidak aktif serta daya tahan tubuh berkurang, sehingga menyebabkan hama belalang tidak nafsu makan dan akhirnya 
akan mati. Jamur patogen dapat membunuh serangga melalui serangkaian proses salah satunya adalah produksi toksin. Produksi toksin telah diteliti pada B. bassiana dimana senyawa toksin dapat melemahkan inang setelah menyerang organ tubuh serangga dan merusak hemolimph sehingga proses metabolisme dalam tubuh serangga terhambat. Dengan terserangnya organ tubuh serangga dan hemolimph, maka aktifitas serangga yang terinfeksi jamur ini biasanya akan berhenti makan, sehingga menjadi lemah sehingga mempercepat kematian (Bell dalam Kumendong,1995). Menurut Plate dalam Soetopo dan Indrayani (2007), serangga bisa mati tidak selalu disertai gejala pertumbuhan spora.

\section{Pengaruh Varietas Kedelai terhadap Intensitas Serangan Belalang, Pertumbuhan dan Hasil Tanaman Kedelai (Glycine max L.)}

Hasil tanaman kedelai berhubungan erat dengan varietas yang ditanam, karena untuk mencapai hasil yang tinggi maka sangat ditentukan oleh potensi genetik dari setiap varietas tersebut (Marliah et al, 2012). Menurut Adisarwanto (2005) bila kondisi lingkungannya tidak baik maka potensi hasil dari varietas unggul tidak dapat tercapai karena interaksi antara faktor genetik dengan kondisi lingkungan berpengaruh terhadap hasil tanaman kedelai. Penampilan tanaman dikendalikan oleh sifat genetik yang dimana dipengaruhi oleh faktor-faktor lingkungan. Kendali genetik pada penampilan tanaman diekspresikan melalui proses biokimia dan fisiologis. Perbedaan susunan genetik merupakan salah satu faktor penyebab keragaman penampilan pada tanaman. Keragaman penampilan tanaman akibat perbedaan susunan genetik mungkin terjadi sekalipun bahan tanam yang digunakan berasal dari jenis tanaman yang sama (Bahri, 2017).

Perlakuan varietas kedelai berpengaruh nyata terhadap tinggi tanaman $70 \mathrm{hst}$, jumlah polong total per tanaman, jumlah polong isi per tanaman, jumlah biji per tanaman dan berat biji per tanaman. Menurut Hakim (2012), tanaman kedelai mempunyai tipe atau karakteristik tanaman yang berbeda antara satu varietas dengan varietas yang lainnya. Pada variabel tinggi tanaman varietas Ijen mempunyai tinggi tanaman paling tinggi yaitu : 77,37 cm. sedangkan varietas Argomulyo (V1) : 71,75 cm, varietas Baluran (V2) : 65,97 cm, dan varietas Kaba (V4) : 72,61 cm. 
Untuk pengamatan jumlah polong, varietas Kaba (V4) menghasilkan jumlah polong total/tanaman 20,62 polong, jumlah polong isi per tanaman : 20,62 polong, jumlah biji : 41,37 biji, dan berat biji 5,89 g yang lebih tinggi diantara varietas lainnya. Varietas Kaba merupakan salah satu varietas unggul nasional yang memiliki warna daun hijau tua, warna bunga ungu, warna kulit biji kuning, warna bulu, hilum dan kulit polong masak coklat dan memiliki bentuk biji lonjong. Kedelai varietas ini umur berbunganya adalah 35 hari dan umur polong masak adalah 85 hari, tinggi tanaman kedelai bisa mencapai $64 \mathrm{~cm}$ sedangkan hasil rata-rata adalah 2,13 ton ha-1 (Puslitbang Tanaman Pangan, 2009). Interaksi antara perlakuan B. bassiana dengan varietas kedelai tidak berpengaruh nyata terhadap semua variabel pengamatan intensitas serangan belalang, pertumbuhan vegetatif dan hasil tanaman kedelai. Hal ini dimungkinkan masing-masing faktor perlakuan lebih berpengaruh secara mandiri.

\section{KESIMPULAN}

1. Perlakuan varietas kedelai berpengaruh nyata terhadap tinggi tanaman $70 \mathrm{hst}$, jumlah polong total/tanaman, jumlah polong isi/tanaman, jumlah biji/tanaman dan berat biji/tanaman. Varietas Kaba (V2) menghasilkan berat biji/tanaman yang paling berat : 5,89 g/tanaman.

2. Perlakuan $B$. bassiana berpengaruh nyata terhadap intensitas serangan belalang. Tanaman kedelai yang diaplikasi B. bassiana (K1) menunjukkan intensitas serangan belalang : 8,66\% sedangkan yang tidak diaplikasikan B. bassiana (K0) menunjukkan intensitas serangan belalang: 17,53\%.

3. Interaksi antara perlakuan varietas kedelai dan B. bassiana tidak berpangaruh nyata terhadap semua variabel yang diamati.

\section{UCAPAN TERIMA KASIH}

Ucapan terima kasih setinggi-tingginya disampaikan kepada UMP yang telah mendanai penelitian ini melalui Skim Penelitian Percepatan Guru Besar tahun 2019.

\section{DAFTAR PUSTAKA}

Adisarwanto. 2006. Budidaya Tanaman Kedelai dengan Penoptimalan Bintil Akar. Agromedia Pustaka. Jakarta. 
Anon, 1991. Food Crops Research Sukamandi 1974-1979. AARD-SURIF, Sukamandi.

Bahri, Syamul. 2017. Respon Pertumbuhan Dan Hasil Tiga Varietas Kedelai (Glycine max, L.) Terhadap Cekaman Kekeringan. Jurnal Penelitian Vol. 4 No. 2 Jul. Universitas Samudra. Aceh.

Balai Penelitian Tanaman Kacang-Kacangan dan Umbi-Umbian. 2015. Deskripsi Varietas Unggul Utama Kacang-Kacangan dan Umbi-Umbian. Balai PenelitianTanaman Kacang-kacangan dan Umbi-Umbian, Malang. 37 hlm.

Balitbang Pertanian. 2009. Pengembangan Kedelai di Kawasan Hutan Sebagai Sumber Benih.Agroinovasi, Jawa Tengah. Hal. 2.

Damardjati, J., S., 2007. Penurunan Harga Kedelai Importir. Ditjen Pengolahan dan Pemasaran Hasil Pertanian Deptan RI, Jakarta.

Firmanto, B.H. 2011. Praktis Bercocok Tanam Kedelai Secara Intensif. Penerbit Angkasa. Bandung

Ghulamahdi, M., Maya, M. dan Danner, S. 2009. Production of Soybean Varieties under Saturated Soil Culture on Tidal Swamps. Indonesian Journal of Agronomy XXXVII No.3. IPB, Bogor : 226-232.

Hakim, L. 2012. Komponen Hasil dan Karakteri Morfologi Penentu Hasil Kedelai. Jurnal Penelitian Pertanian Tanaman Pangan 31 (3). 173 - 179.

Haryono. H Siti N dan Riyanto , 1993. Prospekpenggunaan Beauveria bassiana untuk pengendalian hama tanaman perkebunan dalam simposiumpatologi serangga. Perhimpunan Entomologi Indonesia Cabang Yogyakarta, Yogyakarta.

Hermana, 2003. Pengolahan kedelai menjadi berbagai bahan makanan. Dalam 'Kedelai' cetakan II. penyunting : Sadikin Somaatmadja, M. Ismunadji, Sumarno, Mahyuddin Syam, S.O. Manurung dan Yuswadi. Badan Penelitian dan Pengembangan Pertanian. Pusat Penelitian dabn Pengembangan Tanaman Pangan. Bogor. P $441-469$.

Kardin M.K. dan I.P. Priyatno, 1996. Pemanfaatan Metharizium anisopliae, Beauveria bassiana dan Hirsutella citriformis. Untuk pengendalian serangga pada tanaman pangan dalam kumpulan makalah Pelatihan Agensia Hayati Direktorat Bina Perlindungan Tanaman Pangan, Jakarta.

Kartosuwondo, Utomo 2000. Dasar - dasar Pengendalian Hayati Direktorat Jenderal Tanaman Pangan dan Hortikultura, Direktorat Bina Perlindungan Tanaman Pangan, Jatisari. 
Kumendong C.N. 1995. Patogenesitas jamur Beauveria bassiana terhadap larva Spodoptera exigua pada tanaman bawang daun di laboratorium. Skripsi fakultas pertanian universitas sam ratulangi. Manado.

Marliah, A., T. Hidayat., dan N. Husna. 2012. Pengaruh Varietas dan Jarak Tanam Terhadap Pertumbuhan Kedelai (Glycine Max (L.) Merrill). Jurnal Agrista 16 (1). $22-28$.

Pusat Data dan Sistem Informasi Pertanian. 2015. Buletin Konsumsi Pangan. Pusat Data dan Sistem Informasi Pertanian. Jakarta.

Pusat Penelitian dan Pengembangan Tanaman Pangan. 2015. Badan Penelitian dan Pengembangan Pertanian. http://www.puslittan.bogor.net

Rukmana, R \& Y. Yuniarsih. 1996. Kedelai, Budidaya, dan Pasca Panen. Jakarta: Pustaka Media.

Soetopo, D. dan indrayani, I. 2007. Status teknologi dan prospek Beauveria bassiana untuk pengendalian serangga hama tanaman perkebunan yang ramah lingkungan. Balai penelitian tanaman tembakau dan serat. Malang.

Steinhaus, E. A. 1975. Disease in a Minor Chord. Ohio State University Press, Columbus, Ohio.

Sudarmaji, 1997. Optimasi Pemanfatan Beauveria bassiana untuk pengendalian hama. Makalah di sampaikan pada Pertemuan Teknis Perlindungan Tanaman, Direktorat Bina Perlindungan Tanaman Perkebunan, Ditjen Perkebunan Cipayung 16 - 18 Juni 1997.

Suhartina. 2005. Deskripsi Kultivar Unggul Kacang-kacangan dan Umbi-umbian. Balai Penelitian Tanaman Kacang-kacangan dan Umbi-umbian. Balitkabi.

Tohidin, Antonius T.L. Bey P.M, 2003. Daya bunuh jamurentomopatogen Beauveria bassiana (Balsamo) Vuillemin (Moniliaceae) terhadap Leptocorisa acuta (Hemiptera ; Alydidae) dirumah kaca dalam simposiumpatologi serangga. Perhimpunan Entomologi Indonesia Cabang Yogyakarta.

Wahyudi. 2008. Produksi Mikoinsektisida Dari Propagul KapangBeauveria bassiana. Jurnal Matematika, Sains, dan Teknologi. Vol 9 No 2 (2008). 